\title{
IMPLEMENTASI GREEN ACCOUNTING DALAM MENINGKATKAN KINERJA PERUSAHAAN
}

\author{
Oleh: \\ Wiwik Fitria Ningsih \\ Ratih Rachmawati \\ Program Studi Akuntansi STIE Mandala Jember \\ Email: \\ wiwik@stie-mandala.ac.id
}

\begin{abstract}
The purpose of this paper is to discuss how the implementation of green accounting in improving environmental performance and financial performance. Based on the discussion, it is known that the implementation of green accounting had a positive impact on environmental performance. Improved environmental performance is due to the willingness of companies to comply with government policies and regulations as well as consumer demand for a product that is environmentally friendly. In addition, the implementation of green accounting also affects the company's improved financial performance. With the increase in positive perception of society will increase the loyalty of the people against the company, which in turn was followed by an increase in the sales and profits company. Currently in Indonesia disclosure regarding environmental accounting still not specifically regulated in accounting standards, reporting environmental information in the annual reports of companies is voluntary. Therefore, in this paper, it is advisable for companies to implement green accounting. In the future, the challenge for the Indonesian Institue of Accountants to seek their statements of assets and liabilities as part of the required environment (mandatory) in the financial statements, particularly for industries that are sensitive to issues of environmental destruction.
\end{abstract}

Keyword: Green Accounting, Environmental Performance, Financial Performance. Environmental Sustainability 


\section{A. PENDAHULUAN}

Dampak dari aktivitas manusia terhadap lingkungan alam jika dicermati semakin hari aktivitas manusia semakin banyak dan beragam. Aktivitas manusia dalam memenuhikebutuhan hidupnya dapat menimbulkan dampak terhadap lingkungan. Dampak lingkungan terjadi karena manusia cenderung eksploitatif atau mengambilsumber daya alam dari lingkungan secara berlebihan, tidak lagi sekedar mempertahankan kebutuhan hidup. Akibat dari aktivitas manusia tersebut, lingkungan mengalami kerusakan. Kerusakan lingkungan semakin parah seiring dengan perkembangan perusahaan industri dan teknologi. Pada akhirnya kerusakan lingkungan berdampak buruk pada kehidupan manusia.

Menurut ketua tim peneliti Universitas Adelaide, Corey Bradshaw menyatakan bahwa krisis lingkungan yang kini mencengkram bumi adalah akibat dari konsumsi berlebihan manusia atas sumber daya alam. Semakin kaya suatu negara, semakinbesar dampak kerusakan lingkungan. Indonesia menempati rangking ke empat sebagai negara pling berkontribusi dalam perusakan lingkungan diantaranya Brazil, Amerika Serikat, China dan Indonesia (Kristanti, 2010).

Perusahaan dalam mengelola sumber daya alam berpotensi memiliki resiko negatif terhadap aspek lingkungan hidup. Untuk itu perusahaan perlu menempatkan komitmen terhadap lingkungan hidup maupun lingkungan sosial sebagai hal yang utama dan tidak tepisahkan dari kegiatan operasional perusahaan. Dalam mewujudkannya, perusahaan melengkapi kegiatan operasional dengan dokumen pengelolaan lingkungan yang sesuai dengan ketentuan yang berlaku misalnya Dokumen Analisis Mengenai Dampak Lingkungan. Upaya pengelolaan lingkungan bertujuan untuk memperkirakan dampak yang akan timbul dari kegiatan operasi, mengevaluasi, serta mencari solusi yang tepat untuk menanggulanginya.

Aspek lingkungan menjadi hal yang sensitif karena hal tersebut dapat berpengaruh terhadap keberlanjutan perusahaan (Panggabean dan Deviarti:2012)Dari semakin besarnya dampak yang ditimbulkan dari kegiatan perusahaan terhadap masalah lingkungan dan pelestarian alam, dalam hal ini bidang akuntansi ikut berperan dalam upaya pelestarian lingkungan, yaitu melalui pengungkapan sukarela dalam laporan keuangannya terkait dengan biaya lingkungan. Sistem akuntansi yang didalamnya mengungkapkan akun-akun terkait dengan biaya lingkungan disebut sebagai green accounting atau environmental accounting.

Akuntansi merupakan instrumen yang membantu kepentingan investor dan kreditur serta investor dan kreditur yang potensial dalam pengambilan keputusan (Kustono:2010). Pengungkapan aktivitas lingkungan maupun biaya lingkungan pada laporan tahunan perusahaan akan memberikan gambaran kepada pengguna laporan keuangan perusahaan yang dapat membantu pengguna laporan keuangan dalam pengambilan keputusan untuk program perusahaan terkait dengan pelestarian lingkungan di masa yang akan datang. Program pelestarian lingkungan yang dilakuka oleh perusahaan akan mendapat persepsi positif oleh masyarakat. Pada akhirnya masyarakat akan memiliki kepercayaan yang tinggi terhadap perusahaan. Kepercayaan yang timbul akan mendorong masyarakat menjadi 
konsumen yang loyal bagi perusahaan, dimana loyalitas ini akan meningkatkan penjualan produk yang dikeluarkan perusahaan (Aniela: 2012).

Kinerja lingkungan dapat berpengaruh signifikan terhadap posisi keuangan perusahaan. Hal ini juga menunjukkan perlunya informasi biaya lingkungan yang memadai (Hansen dan Mowen: 2009) Pengungkapan biaya lingkungan pada sistem akuntansi disebut dengan akuntansi lingkungan atau green accounting.Tujuan penulisan ini adalah untuk membahas mengenaibagaimana dampak dari implementasi green accounting dalam meningkatkan kinerja lingkungan dan kinerja keuangan perusahaan.

\section{B. TINJAUAN PUSTAKA}

\section{Pengertian Akuntansi Lingkungan}

Menurut Cohen dan Robbins (2011) Green accounting atau environmental accounting didefinisikan sebagai:

"a style of accounting that includes the indirects costs and benefits of economic activity-such as environental effects and health consequences of businss decisions and plans"

Artinya adalah akuntansi lingkungan merupakan jenis akuntansi yang memasukkan biaya dan manfaat tidak langsung dari aktivitas ekonomi, seperti dampak lingkungan dan konsekuensi kesehatan dari perencanaan dan keputusan bisnis.

Menurut Ikhsan (2008) definisi dari akuntansi lingkungan adalah sebagai pencegahan, pengurangan, dan atau penghindaran dampak terhadap lingkungan, bergerak dari beberapa kesempatan, dimulai dari perbaikan kembali kejadiankejadian yang menimbulkan bencana atas kegiatan-kegiatan tersebut.

Berdasarkan definisi green accounting diatas maka dapat disimpulkan bahwa green accounting merupakan akuntansi yang didalamnya mengungkapkan biaya-biaya terkait dengan aktivitas perusahaan yang berhubungan dengan lingkungan.

\section{Tujuan Akuntansi Lingkungan}

Banyak perhatian mengenai persoalanlingkungan menjadi penting untuk mempertimbangkan akuntansil lingkungan. Menurut Pramanik, et al (2007) tujuan akuntansi lingkungan diantaranya adalah mendorong pertanggungjawaban entitas dan meningkatkan transparansi lingkungan, membantu entitas dalam menetapkan strategi untuk menanggapi isu lingkungan hidup dalam konteks hubungan entitas dengan masyarakat dan terlebih dnegan kelompok-kelompok aktivis terkait isu lingkungan, memberikan citra yang lebih positif sehingga entitas dapat memperoleh dana dari kelompok dan individu "hijau" seiring dengan tuntutan etis dari investor yang semakin meningkat, mendorong konsumen untuk membeli produk hijau dan dengan demikian membuat entitas mempunyai keunggulan pemasaran yang lebih kompetitif dibandingkan dengan entitas yang tidak melakukan pengungkapan, menunjukkan komitmen entitas terhadap usaha perbaikan lingkungan hidup, dan mencegah opini negatif publik mengingat perusahaan yang berusaha pada area yang beresiko tidak ramah lingkungan pada umumnya akan menerima tentangan dari masyarakat. 
Implementasi green accounting sebagai bagian dari sistem akuntansi perusahaan perlu untuk dipertimbangkan karena memungkinkan untuk megurangi dan menghapus biaya-biaya lingkungan, memperbaik kinerja lingkungan perusahaan yang selama ini mungkin mempunyai dampak negatif terhadap kesehatan manusiadan keberhasilan bisnis perusahaan, diharapkan menghasilkan biaya atau harga yang lebih akuratterhadap produk dari proses lingkungan yang diinginkan dan memungkinkan pemenuhan kebtuhan pelanggan yang mengharapkan produk/jasa lingkungan yang lebih bersahabat. Tujuan dari green accounting sebagai sebuah alat managemen lingkungan dan sebagai alat komunikasi dengan masyarakat (Ikhsan: 2008).

Green accounting merupakan media komunikasi dengan publik untuk menyampaikan jika sebuah organisasi serius memperbaiki kinerja lingkungannya. Tujuan dari perbaikan kinerja lingkungan adalah mengusulkan kinerja perbaikan berkelanjutan untuk pengendalian lingkungan (Hansen dan Mowen: 2009).Green accounting dapat memperbaiki kinerja lingkungan, pengendalian biaya, investasi dengan teknologi yang ramah lingkungan, mendorong pada proses produk yang ramah lingkungan. Akuntansi lingkungan sangat bermanfaat karena dapat digunakan untuk mengelola biaya lingkungan lebih baik, merumuskan strategi bisis, menghitung biaya produksi lebih akurat, dan menemukan peuang baru untuk menekan biaya lingkungan. Akuntansi lingkungan atau greenaccounting juga memberikan peluang untuk meminimalisasi energi, konservasi sumber daya, mengurangi resiko lingkungan terhadap kesehatan, keamanan dan mendorong kearah keunggulan kompetitif.

\section{Kinerja Lingkungan}

Menurut Suratno (2006) kinerja lingkungan perusahaan merupakan kierja perusahaan dalam menciptakan lingkungan yang baik. Kinerja lingkunan perusahaan berfokus pada kegiatan perusahaan dalam melestarikan lingkungan dan mengurangi dampak negatif lingkungan yang timbul akibat aktivitas perusahaan.

Program penilaian peringkat kinerja perusahaan dalam pegelolaan lingkungan hidup atau sering disebut proper dapat dijadikan pilihan dalam mengukur kinerja lingkungan perusahaan yang ada di indonesia. PROPER merupakan program pemeringkat lingkungan dari kementrian Lingkungan Hidup. Penggunaan warna di dalam penilaian proper merupakan bentuk komunikatif penyampaian kinerja kepada masyarakat, mulai dari yang terbaik, emas, hijau, biru, merah sampai yang terburuk, hitam. Secara sederhana masyarakat apat mengetahui tingkat penataan pengelolaan lingkungan pada perusahaan dengan melihat peringkat warna yang ada.

Aspek penilaian PROPER adalah ketaatan terhadap peraturan pengendalian pencemaran air, pengendalian pencemaran udara, pengendalian limbah B3, AMDAL, serta pengendalian pencemaran laut. Ketentuan ini bersifat wajib untuk dipenuhi. Jika perusahaan memenuhi seluruh peraturan tersebut maka akan diperoleh peringkat BIRU, jika tidak maka akan memperoleh peringkat MERAH atau HITAM, tergantung pada aspek ketidak-taatannya. Berdasarkan peraturan Nomor 6 tahun 2013 tentang Program Penilaian Peringkat Kinerja Perusahaan 
dalam Pengelolaan Lingkungan Hidup, perusahaan yang berperingkat hitam langsung dierahkan kepada proses penegak hukum sedangkan prusahaan yang berepringkat merah akan dimasukkan dalam pembinaan untuk pebaikan kinerja pengelolaan lingkungan.

\section{Kinerja Keuangan Perusahaan}

Kinerja keuangan adalah kinerja perusahaan secara relatif (berubah-ubah) dalam suatu industri sejenis yang ditandai dengan return tahunan perusahaan tersebut (Almilia: 2007). Menurut Sucipto (2003) kinerja keuangan perusahaan merupakan hasil dari banyak keputusan individual yang dibuat secara terus menerus oleh managemen. Oleh karena itu untuk menilai kinerja keuangan suatu perusahaan, perlu dilibatka analisa dampak keuangan kumulatif dan ekonomi dari keputusan dan mempertimbangkannya dengan menggunakan ukuran komparatif. Kinerja keuangan merupakan penentuan ukura-ukuran tertentu yang dapat mengukur keberhasilan suatu perusahaan dalam menghasilkan laba (Sucipto, 2003). Dengan kata lain, kinerja keuangan perusahaan dapat dilihat dari tingkat profitabilitas perusahaan.

Menurut Murdoko dan Lana (2007) proftabilitas merupakan suatu indikator kinerja yang dilakukan managemen dalam mengelola kekayaan perusahaan yang ditunjukkan oleh laba yang dihasilkan. Pengukuran rasio profitabilitas dapat menggunakan ROA (Return On Asset) dan ROS (Return On Sales).

\section{Return On Assets (ROA)}

Return On Assets atau disebut juga rentabilitas ekonomi ialah laba usaha dengan modal sendiri dan modal asing yang dipergunakan untuk menghasilkan laba dan dinyatakan dalam persentase (Riyanto: 2001). Rasio ini digunakan untuk mengukur tingkat pengembalian investasi yang telah dilakukan perusahaan dengan menggunakan seluruh aktiva yang dimilikinya. Semakin tinggi ROA semakin tinggi keuntungan.

\section{Return On Sales (ROS)}

Return on sales atau disebut juga dengan Net profit margin adalah rasio yang digunakan untuk menunjukkan kemampuan perusahaan dalam menghasilkan keuntungan bersih setelah dipotong pajak. Net Profit Margin menurut Riyanto (2001) ditentukan oleh dua faktor yaitu penjualan bersih dan pendapatan bersih. Dengan jumlah penjualan tertentu, rasio profit margin dapat diperbesar dengan menekan atau memperkecil biaya operasional.

\section{PEMBAHASAN}

\section{Implementasi Green Accountingdalam Meningkatkan Kinerja Lingkungan dan Kinerja Keuangan Perusahaan}

Green accounting yang mulai berkembang beberapa dekade lalu kini makin berperan dalam mempertinggi nilai ekonomi dan meningkatkan perlindungan lingkungan. Data dan informasi yang disajikan digunakan sebagai bahan 
pengambilan keputusan dalam berbagai organisasi bisnis, pemerintah dan organisasi sosial. Misalnya pengambilan keputusan untuk pengendalian biaya, perbaikan ekologi, investasi teknologi yang ramah lingkungan, pengembangan proses produksi bersih, dan sebagainya (Auliyah, 2009: halaman..)

Implementasi green accounting umumnya dilakukan oleh perusahaan yang memiliki perhatian dan minatterhadap kelestarian lingkungan, kebersinambungan (sustainability), efektivitas linkungan (ecoeffectiveness), efesiensi lingkungan (ecoefficiency), dan menerapkannyasecara langsung dengan banyak sarana pemasaran dalam managemen strategik (Cohen dan Robbins: 2011)

Melalui implementasi green accounting maka diharapkan lingkungan akan terjaga kelestariaannya, karena dalam menerapkan green accounting maka perusahaan akan secara sukarela mematuhi kebijakan pemerintah dimana perusahaan tersebut menjalankan bisnisnya (Aniela: 2011).

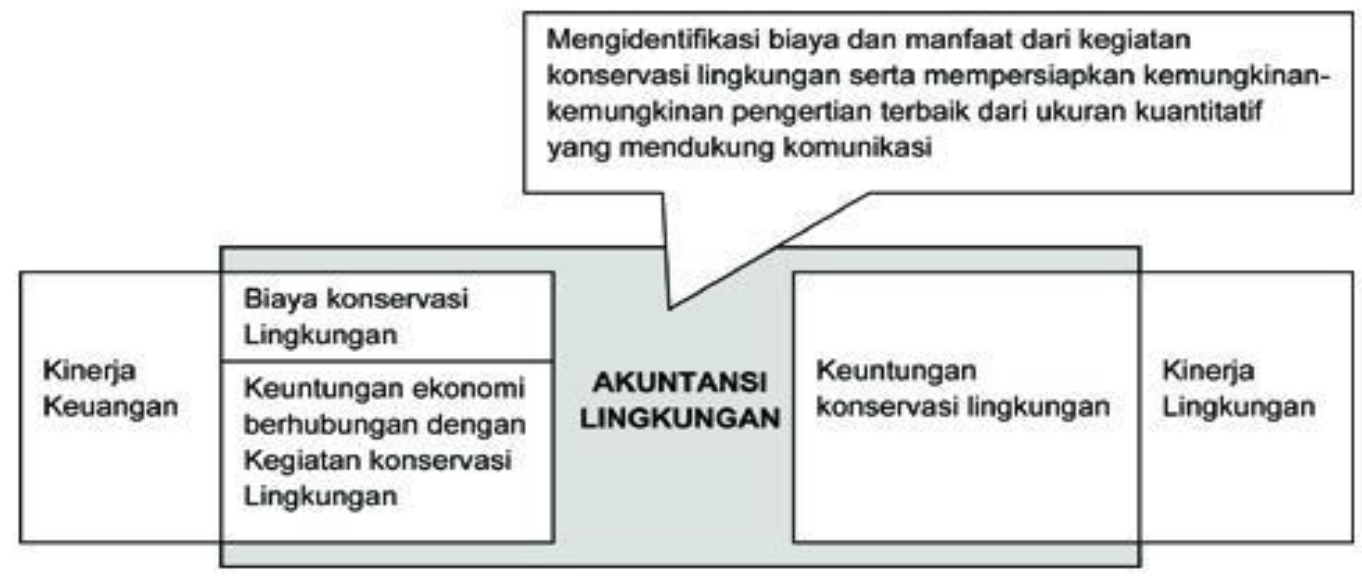

Sumber: Ministry of The Environmental Japan, 2005: Environmental Accounting Guidelines

Gambar 4.1

Hubungan Akuntansi Lingkungan Dengan Kinerja Lingkungan Dan Kinerja Keuangan

Hubungan antara akuntansi lingkungan dengan kinerja lingkungan dan kinerja keuangan dapat dilihat pada gambar 4.1. jadi konsep akuntansi lingkungan mengikuti tiga faktor yaitu pertama, biaya konservasi lingkungan yang diukur dengan menggunakan nilai satuan uang; kedua, keuntungan ekonomi dari kegiatan konservasi lingkungan yang diukur dengan nilai satuan uang, kedua faktor tersebut aka mempengaruhi kinerja keuangan; dan faktor ketiga adalah keuntungan konservasi lingkungan yang diukur dengan unit fisik, dimana semakin baikkeuntungan konservasi lingkungan akan mempengaruhi kinerja lingkungan perusahaan.

Kementerian Lingkungan Hidup (Ministry of Environment) mengeluarkan panduan akuntansi lingkungan (Environmental Accounting Guidelines) pada tahun 2005. Semua perusahaan di Jepang wajib menerapkan akuntansi lingkungan. Perusahaan-perusahaan besar di Jepang mulai menemptkan posisi akuntansi lingkungan (green accounting) sederajat dengan akuntansi keuangan. 
Banyak perusahaan di Jepang sudah menerapkan akunatnsi lingkungan sesuai dengan peraturan perundangan dan petunjuk yang dikeluarkan oleh Kementerian Lingkungan Hidup jepang (Sukma: 2013)

Berdasarkan penelitian yang dilakukan oleh Nuryanti, dkk (2015) untuk menilai pengaruh green accounting terhadap kinerja lingkungan pada perusahaan tekstil di Bandung yang mengikuti PROPER yang diteliti dengan menggunakan regresi linier berganda. Hasil penelitian Nuryanti, dkk (2015) menunjukkan bahwa Akuntansi Lingkungan mempunyai pengaruh signfikan terhadap Kinerja Lingkungan. Respon perubahan kinerja lingkungan akibat perubahan Akuntansi Lingkungan adalah positif atau searah. Makin baik green accounting akan diikuti kinerja Lingkungan pada perusahaan tekstil di wilayah Bandung yang mengikuti PROPER makin tinggi. Green accountning memberikan pengaruh sebesar 97,4\% terhadap kinerja lingkungan pada perusahaan tekstil di wilayah bandung yang mengikuti PROPER. Pengaruh sebesar 97,4\% tergolong pengaruh yang besar dan memiliki makna yang signifikan.

Selain itu, penelitian yang dilakukan oleh de Beer dan Friend (2005) membuktikan bahwa pengungkapan biaya lingkungan, baik internal maupun eksternal, dan mengalokasikan biaya-biayaini berdasarkan type biaya dan pemacu biaya dalam sebuah green accounting yang terstruktur akan memberikan kontribusi baik pada kinerja lingkungan.

Penelitian yang dilakukan oleh Burhany (2011) meneliti pengaruh penerapan akuntansi lingkungan pada kinerja lingkungan dan pengungkapan informasi lingkungan dan dampaknya terhadap kinerja keuangan perusahaan. Responden adalah Divisi Manager Akuntansi 30 perusahaan pertambangan umum ikut serta dalam periode 2008-2009. Data primer yang dikumpulkan dengan menggunakan kuesioner sementara data sekunder dikumpulkan dari publikasi internet dan langsung dari perusahaan. Metode analisis jalur diterapkan untuk menguji hipotesis dengan menggunakan 8,70 Lisrel. perangkat lunak hasil studi ini menunjukkan bahwa: (1) implementasi green accounting memiliki pengaruh yang signifikan dan positif pada kinerja lingkungan, (2) pelaksanaan green accounting dan kinerja lingkungan memiliki pengaruh yang signifikan dan positif pada pengungkapan informasi lingkungan, baik secara bersamaan dan sebagian, dan (3) implementasi green accounting, kinerja lingkungan, dan pengungkapan informasi lingkungan memiliki pengaruh yang signifikan dan positif pada kinerja keuangan secara bersamaan, tetapi hanya implementasi green accounting dan kinerja lingkungan memiliki pengaruh yang signifikan dan positif pada kinerja keuangan.

Pelaporan informasi lingkungan memiliki manfaat bagi perusahaan. Bewley (2008) menemukan bahwa perusahaan menggunakan pengungkapan lingkungan untuk membedakan perusahaan dengan perusahaan lain. Green accounting tidak terbatas pada akuntansi keuangan, tetapi juga diterapkan pada akuntansi managemen, akuntansi managemen lingkungan digunakan untuk memonitor dan mengevaluasi efisiensi penggunaan sumber daya, megurangi dampak lingkungan dari operasi perusahaan

Menurut Auliyah (2009) salah satu cara untuk melestarikan lingkungan hidup adalah menggunakan analisis dampak lingkungan hidup (AMDAL) pada 
setiap perusahaan yang melakukan kegiatan yang diperkirakan mempunyai dampak signifikan terhadap lingkungan. Dengan adanya penyelenggaraan green accounting menjadi suatu media akuntanbilitas dan dasar keputusan bagi pihak stakeholder.

Dengan demikian dapat disimpulkan bahwa perusahaan yang mengimplementasikan green accountingmaka perusahaan tersebut akan mendukung kinerja lingkungan dan kinerja keuangan perusahaan. Fungsi dan peran green accounting dibagi kedalam dua bentuk yaitu fungsi internal dan fungsi eksternal (Ikhsan, 2008). Fungsi internal merupakan fungsi yang berkaitan pihak internal perusahaan sendiri. Fungsi internal memungkinkan untuk mengukur biaya konservasi lingkungan dan menganalisis biaya-biaya dari kegiatan konservasi lingkungan yang efektif dan efisien serta sesuai dengan pengambilan keputusan. Dalam fungsi internal diharapkan akuntansi lingkungan berfungsi sebagai alat managemen bisnis yang dapat digunakan oleh manager ketika berhubungan dengan unit-unit bisnis. Sedangkan fungsi eksternal merupakan fungsi yang berkaitan dengan aspek pelaporan keuangan. Pada pelaporan keuangan perlu diperhatikan pengungkapan hasil dari kegiatan konservasi lingkungan dalam bentuk data akuntansi. Informasi yang diungkapkan diukur secara kuantitatif dari kegiatan konversi lingkungan. Fungsi eksternal memberi kewenangan bagi perusahaan untuk mempengaruhi pengambilan keputusan stakeholders seperti pelanggan, rekan bisnis, investor, maupun kreditor.

Panggabean dan Deviarti (2012) dalam penelitiannya mengungkapkan bahwa PT Timah belum menerapkan akuntansi lingkungan secara penuh. Padahal cukup banyak data yang dapat digunakan untuk menunjang penerapan akuntansi lingkungan. Saat ini di Indonesia pengungkapan mengenai akunatnsi lingkungan masih belum diatur secara khusus dalam standar akuntansi, pelaporan informasi lingkungan dalam laporan tahunan perusahaan masih bersifat sukarela. Penjelasan dalam PSAK No.1 paragraf 15 tahun 2012 tentang laporan keuangan, yang menyatakan:

Entitas dapat pula menyajikan, terpisah dari laporan keuangan, laporan mengenai lingkungan hidup dan laporan nilai tambah, khususnya bagi industri dimana faktor lingkungan hidup memegang peranan penting dan bagi industri yang menganggap karyawan sebagai kelompok pengguna laporan keuangan yang memegang peranan penting. Laporan tambahan tersebut diluar ruang lingkup Stadar Akuntansi Keuangan.

Oleh karena itu, dalam penulisan ini disarankan bagi perusahaan untuk mengimplimentasikan green accounting. Di masa mendatang, merupakan tantangan bagi Ikakan Akuntansi Indonesia untuk mengupayakan adanya laporan aset dan kewajiban lingkungan sebagai bagian yang diharuskan (mandatory) dalam laporan keuangan, terutama untuk industri yang sensitif terhadap isu perusakan lingkungan hidup. Akuntansi lingkungan atau green accouting akan mendukung kualitas kinerja lingkungan dan kenerja keuangan perusahaan. Dengan adanya keharusan untuk menyampaikan aspek lingkungan dalam laporan keuangan dapat melindungi stakeholders dari hanya sekedar mendapatkan citra organisasi yang ramah lingkungan. 


\section{KESIMPULAN}

Melalui implementasi green accounting maka diharapkan lingkungan akan terjaga kelestariaannya, karena dalam menerapkan green accounting maka perusahaan akan secara sukarela mematuhi kebijakan pemerintah dimana perusahaan tersebut menjalankan bisnisnya, selain itu juga diikuti oleh meningkatnya persepsi positif dari masyarakat akan meningkatkan loyalitas masyarakat terhadap perusahaan yang pada akhirnya diikuti oleh peningkatan penjualan perusahaan dan laba peusahaan. Saat ini di Indonesia pengungkapan mengenai akuntansi lingkungan masih belum diatur secara khusus dalam standar akuntansi, pelaporan informasi lingkungan dalam laporan tahunan perusahaan masih bersifat sukarela. Oleh karena itu, dalam penulisan ini disarankan bagi perusahaan untuk mengimplimentasikan green accounting. Di masa mendatang, merupakan tantangan bagi Ikatan Akuntansi Indonesia untuk mengupayakan adanya laporan aset dan kewajiban lingkungan sebagai bagian yang diharuskan (mandatory) dalam laporan keuangan, terutama untuk industri yang sensitif terhadap isu perusakan lingkungan hidup.

\section{DAFTAR PUSTAKA}

Almilia, Luciana Spica. (2007). Pengaruh Environmental Performance Dan Environmental Disclosure Terhadap Economic Performance. Proceeding the First Accounting Conference.Depok, 7-9 November 2007

Aniela, Yoshi. (2012). Peran Akuntansi Lingkungan Dalam Meningkatkan Kinerja Lingkungan Dan Kinerja Keuangan Perusahaan. Berkala Ilmiah Mahasiswa Akuntansi.Vol.1 No.1, Januari 2012. Hal.15-19

Auliyah, Robiatul. (2009). Akuntansi Lingkungan Dalam Wacana Good Governance. Jurnal Infestasi Vol 5. No 2, Desember 2009. Hal.96-112

Bewley. (2008). The Impact Of A Change In Regulatioan On Environmental Disclosure: SAB92 And The Us Chemical Industry. Issues In Social And Environmental Accounting. Vol.2 No.1, June 2008. pp.61-88

Burhany, Imanina. (2011). Pengaruh Implementasi Akuntansi Lingkungan Terhadap Kinerja Lingkungan Dan Pengungkapan Informasi Lingkungan Serta Dampaknya Terhadap Kinerja Keuangan Perusahan. Indonesian Journal of Economics and Business. Vol.1, No 2

Cohen, N., dan P, Robbins. (2011). Green Business: An A-to-Z Guide. Thousand Oaks, California: SAGE Publications Inc.

de Beer, P., dan F. Friend. (2005). Environmental Accounting: A Management Tool For Enhancing Corporate Environmental And Economic Performance. Ecological Economic 58. pp.548-560 
W. Fitria dan R. Rachmawati /Journal of Applied Business and Economics Vol. 4 No. 2 (Desember

Hansen dan Mowen. (2009). Akuntansi Managerial. Jakarta: Penerbit Salemba Empat

Ikhsan, Arfan. (2008). Akuntansi Lingkungan . Yogyakarta:Graha Ilmu

Kristanti, Elin Yunita. (2010). Indonesia Rangking Empat Perusak Lingkungan. viva.co.id Jumat 7 mei 2010.

Kustono, Alwan Sri. (2010). Menuju Pabu Yang Menetapi Tujuan Nasional. Jurnal Ekonom Akunatnsi Dan Managemen. Vol IX No.1, April 2010. hal.1-11

Ministry of The Environmental Japan. (2005). Environmental Accounting Guidelines 2005. www.env.go.jp/en/earth

Nuryanti, Tira Novi., Nurlely., dan Rosdiana, Yuni. (2015). Pengaruh Akuntansi Lingkungan Terhadap Kinerja Lingkungan (Pada Peusahaan Tektstil Wilayah Bandung). Prosiding Penelitian SPeSIA

Panggabean, Rosinta ria dan deviarti, Holly. (2012). Evaluasi Pengungkapan Akuntansi Lingkungan Dalam Perspektif Pt Timah (Persero) Tbk. Binus Business Review Vol.3 No.2 November 2012, hal.1010-1028

Pramanik, Alok Kumar, Shil, Nikhil Chandra and Das, Bhagaban.(2007). Environmental Accounting and Reporting: with Special Reference to India, (31 December 2007), http://mpra.ub.uni-muenchen.de/7712/

Riyanto, Bambang. (2001). Dasar-dasar Pembelanjaan Perusahaan. Yogyakarta: Penerbit BPFE

Sucipto. (2003). Penilaian Kinerja Keuangan. Jurnal akuntansi by USU Digital Library

Sukma, Devani. (2013). Apa Sebenarnya Akuntansi Lingkungan.(http://keuanganlsm.com)

Suratno, Ignatius Bondan. (2006). Pengaruh Environmental Perfomance Terhadap Environmental Disclosure Dan Eonomic Performance (Study Empiis Pada Perusahaan Manufactur Yang Terdaftar Di Bursaefek Jakarta Periode 2001-2004). Jurnal Riset akuntansi indonesia. Vol.10, No.2, Mei 2007 